\title{
Single and combinatorial herbal formulations reversed hyperglycemia and dyslipidemia in diabetic
}

\section{rats}

\begin{abstract}
Background and Objective: Traditional herbs are often administered in form of multiherbal recipes, which is presumed to exhibit better efficacy than mono-herbal formulations. The current study sought to evaluate the capacities of single herbal formulations (SHFs), double herbal formulations (DHFs), triple herbal formulations (THFs) and quadruple herbal formulation (QHF) of leaf extracts of Acanthus montanus, Asystasia gangetica, Gongronema latifolium and Solanum melongena to reverse hyperglycemia and dyslipidemia in diabetic rats (DM-r). Materials and Methods: Diabetes mellitus (DM) was induced in the rats by single intra-peritoneal (i.p.) injection of $90 \mathrm{mg} / \mathrm{kg}$ body weight (b.w.) of alloxan monohydrate in phosphate buffered saline $(\mathrm{pH}=7.4)$. The rats with fasting plasma glucose concentration $(\mathrm{FPGC})>110 \mathrm{mg} / \mathrm{dL}$ for 5 consecutive days were considered diabetic and treated with the herbal formulations for 21 consecutive days. FPGC and serum lipid profile of the rats were measured according to standard methods. Results: Combined dose (ratio:1:1 $w / w)$ of $A$. gangetica + A. montanus $(200 \mathrm{mg} / \mathrm{kg} \mathrm{b.w}$.) exerted the greatest glycemic control in DM-r, which corresponded to FPBC of $107.2 \pm 5.42 \mathrm{mg} / \mathrm{dL}$. Additionally, combined doses (ratio: 1:1 w/w) of A. gangetica + A. montanus (200 mg/kg b.w.) and A. gangetica + G. latifolium (200 $\mathrm{mg} / \mathrm{kg}$ b.w.) substantially reversed dyslipidemia in DM-r. Conclusion: The present study showed that selected DHFs offered greater glycemic control than other herbal formulations and reversed dyslipidemia in the experimental rat groups. However, all herbal formulations did not offer full therapeutic benefit within the experimental time of 21 days.
\end{abstract}

Keywords: Diabetes mellitus, dyslipidemia, herbal formulations, hyperglycemia
Volume 6 Issue I - 2019

\author{
Chinwendu Maureen Chikezie,' Okey \\ Alphonsus Ojiako,' Adamma Angela \\ Emejulu,' Paul Chidoka Chikezie ${ }^{2}$ \\ 'Department of Biochemistry, Federal University of Technology, \\ Nigeria \\ ${ }^{2}$ Department of Biochemistry, Imo State University, Nigeria
}

Correspondence: Paul Chidoka Chikezie, Department of Biochemistry, Imo State University, Nigeria, Tel +234 80389353 27,Email P_chikezie@yahoo.com

Received: January 28, 2019 | Published: February 12, 2019

\section{Introduction}

Acanthus montanus (Nees) T. Anderson is widespread in Africa, the Balkans, Romania, Greece and Eastern Mediterranean and belongs to the family of Acantheceae. The leaves are dark green and measure about $30 \mathrm{~cm}$ long. Common names of $A$. montanus are mountain thistle or Devil's fig or Bear's Breech. The leaf extracts of $A$. montanus have been previously reported to exhibit analgesics, antipyretic, antimicrobial, anti-inflammatory and immunological properties. $^{1}$

Asystasia gangetica L. T. Anderson is a perennial herbaceous plant with oval leaves, covered on both sides with short sparse hairs, which measure between 5 to $10 \mathrm{~cm}$ long and 3 to $6 \mathrm{~cm}$ wide. Decoctions of $A$. gangetica are used in African and Asian ethno medicinal practices as antitumor, purgatives, anti-inflammatory, antioxidants and antidotes. ${ }^{2}$

Gongronema latifolium Benth et Hook (Asclepiadaceous) is a climbing shrub commonly found in tropical rainforest and primarily used as spice and vegetable in traditional folk medicine in Southern parts of Nigeria. ${ }^{3,4}$ Akuodor et al., ${ }^{5}$ reported that G. latifolium has antiplasmodial activity; this supports the traditional use of the leaf extract of the plant for local treatment of malaria. Reports by Egunyomi et al., ${ }^{6}$ showed that $G$. latifolium has antisickling activities and effective in the treatment of sore gums, colic, dyspepsia and anti-helminthic.

Solanum melongena L.Var inerme D.C Hiern (Eggplant) are highly cherished and consumed in Nigeria. In indigenous medicinal practices, eggplant is used to achieve weight reduction in obese individuals as well as treatment of several ailments like asthma, skin infections and constipation. Additionally, decoctions of the plant parts possess analgesic, antipyretic, antioxidant, anti-inflammatory, antiasthmatic, hypertensive, ant platelet, intraocular pressure reducing, CNS depressant and anaphylactic reaction inhibitory activities. ${ }^{7}$ The phytochemical and nutrient compositions of A. montanus, A. gangetica, G. latifolium and S. melongena have been mentioned by several authors. ${ }^{1,4,8-10}$

The global prevalence of diabetes mellitus (DM) is on the rise and was estimated to be over 171 million in 2000 with a projection of over 366 million in 2030. ${ }^{11}$ Type II DM is rapidly emerging as a major public health challenge in Nigeria. ${ }^{12}$ In 2003, the International Diabetes Federation (IDF) reported DM prevalence of $3.4 \%$ for 24 million Nigerians between the ages of 20 and 79 years with a projection of $3.9 \%$ by $2025 .{ }^{12} \mathrm{DM}$ induced-metabolic disorders elicit micro- and macro-vascular complications. ${ }^{13}$ The clinical classification of DM has been described elsewhere. ${ }^{14}$ Furthermore, studies have shown that DM promotes atherogenic dyslipidemia by enhancing hepatic secretion of VLDL-C. ${ }^{15}$ Additionally, metabolic tracer studies have documented overproduction of VLDL-C and TAG in insulinresistant patients presenting hypertriglyceridemia. ${ }^{16}$

Medicinal plants continue to provide valuable therapeutic recipes, in orthodox and traditional healing systems, for amelioration of diseases and disorders. Studies have shown that in spite of availability of orthodox anti-DM therapeutics, medicinal plants are still commonly used as herbal remedies for amelioration of DM. ${ }^{17}$ The renewed 
interest in herbal anti-diabetic remedies is believed to be motivated by the fact that traditional plant medicines offer cost-effective mitigation strategies. ${ }^{18}$ Traditional herbs are often administered in the form of multi-herbal recipes, which is presumed to exhibit better efficacy than the mono-herbal formulations. ${ }^{19}$ The current study sought to evaluate the capacities of single herbal formulations (SHFs), double herbal formulations (DHFs), triple herbal formulations (THFs) and quadruple herbal formulation (QHF) of leaf extracts of $A$. montanus, A. gangetica, G. latifolium and S. melongena to reverse hyperglycemia and dyslipidemia in diabetic rats (DM-r).

\section{Materials and methods}

\section{Collection and preparation of samples}

Collection and preparation of the leaves for extraction was according to the methods previously described. ${ }^{20}$ All the leaves were collected between the months of July and August, 2016.

\section{Preparation of leaf extracts}

Preparation of ethanolic leaf extracts of the four ground samples was according to the methods previously described. ${ }^{20}$ Appropriate doses of single and combinatorial leaf extracts were prepared and administered to the rats.

\section{Experimental animals/ethics}

Male Wistar albino rats of average weight of $197.3 \mathrm{~g}$ were purchased from a commercial animal house in Owerri-North LGA, Imo State, Nigeria. The rats were housed in well-ventilated metal cages and maintained at room temperature of $28 \pm 2{ }^{\circ} \mathrm{C}, 30-55 \%$ of relative humidity on a 12-h light/12-h dark cycle, with access to water and pelletized standard guinea feed (PSGF) (United Africa Company Nigeria Plc., Jos, Nigeria) ad libitum. They were kept for 2 weeks to acclimatize to environmental conditions. The present study was approved by the Ethical Committee on the use of animals for research, Department of Biochemistry, Federal University Technology, Owerri, Nigeria (Ethics Approval Number: ODVC/REN/990/255). Handling of the rats was in accordance with the standard principles of laboratory animal care of the United States National Institutes of Health (NIH, 1978).

\section{Induction of diabetes mellitus/experimental design}

Single intra-peritoneal (i.p.) injection of $90 \mathrm{mg} / \mathrm{kg} \mathrm{b.w.} \mathrm{of} \mathrm{alloxan}$ monohydrate (Sigma, St. Louis, USA) in PBS $(\mathrm{pH}=7.4)$ was administered to the rats to induce diabetes mellitus (DM) ${ }^{20} \mathrm{~A}$ fasting plasma glucose concentration (FPGC) $>110 \mathrm{mg} / \mathrm{dL}$ in the rats for 5 consecutive days were considered a diabetic state and selected for the experiment. A total of 102 male Wistar rats were divided into seventeen (17) groups of six (6) rats each. The rats were not given food and water for $16 \mathrm{~h}$ prior to the commencement of herbal treatment as previously described..$^{20}$ The animal groups were treated by oral gavage on daily basis for 21 days and were grouped on the basis of treatments given as previously described. ${ }^{21}$ All the rats (Groups 1-17) were given PSGF + water ad libitum

I. Group 1 (NORM): Normal rats were given $1.0 \mathrm{~mL} / \mathrm{kg}$ b.w. of PBS.

II. Group 2 (DIAB): DM-r was given $1.0 \mathrm{~mL} / \mathrm{kg} b . w$. of PBS.

III. Group 3 (DM-rACMO): DM-r was given A. montanus (200 $\mathrm{mg} / \mathrm{kg}$ b.w. in PBS).

IV. Group 4 (DM-rASGA): DM-r was given A. gangetica (200 mg/ $\mathrm{kg}$ b.w. in PBS).
V. Group 5 (DM-rGOLA): DM-r was given G. latifolium (200 mg/ $\mathrm{kg} b . w$. in PBS).

VI. Group 6 (DM-rSOME): DM-r was given S. melongena (200 $\mathrm{mg} / \mathrm{kg}$ b.w. in PBS)

VII. Group 7 (DM-rAGAM): DM-r was given combined dose (ratio: 1:1 w/w) of A. gangetica + A. montanus $(200 \mathrm{mg} / \mathrm{kg} \mathrm{b.w.}$ in PBS).

VIII. Group 8 (DM-rAGGL): DM-r was given combined dose (ratio: $1: 1 \mathrm{w} / \mathrm{w})$ of $A$. gangetica + G. latifolium $(200 \mathrm{mg} / \mathrm{kg} \mathrm{b.w.} \mathrm{in}$ PBS).

IX. Group 9 (DM-rAGSM): DM-r was given combined dose (ratio: $1: 1 w / w)$ of A. gangetica $+S$. melongena $(200 \mathrm{mg} / \mathrm{kg} \mathrm{b.w.} \mathrm{in}$ PBS).

X. Group 10 (DM-rAMGL): DM-r was given combined dose (ratio: 1:1 w/w) of A. montanus + G. latifolium $(200 \mathrm{mg} / \mathrm{kg}$ b.w. in PBS).

XI. Group 11 (DM-rAMSM): DM-r was given combined dose (ratio: $1: 1 w / w)$ of $A$. montanus $+S$. melongena $(200 \mathrm{mg} / \mathrm{kg}$ b.w. in PBS).

XII. Group 12 (DM-rGLSM): DM-r was given combined dose (ratio: $1: 1 \mathrm{w} / \mathrm{w})$ of $\mathrm{G}$. latifolium $+S$. melongena $(200 \mathrm{mg} / \mathrm{kg}$ b.w. in PBS).

XIII. Group 13 (DM-rAGGS): DM-r was given combined dose (ratio: $1: 1: 1 w / w)$ of $A$. gangetica + G. latifolium + S. melongena $(200$ $\mathrm{mg} / \mathrm{kg}$ b.w. in PBS).

XIV. Group 14 (DM-rAMAG): DM-r was given combined dose (ratio: 1:1:1 w/w) of A. montanus + A. gangetica + G. latifolium (200 mg/kg b.w. in PBS).

XV. Group 15 (DM-rAMAS): DM-r was given combined dose (ratio: 1:1:1 w/w) of A. montanus + A. gangetica $+S$. melongena (200 $\mathrm{mg} / \mathrm{kg}$ b.w. in PBS).

XVI. Group 16 (DM-rAMGS): DM-r was given combined dose (ratio: 1:1:1 w/w) of A. montanus + G. latifolium + S. melongena (200 mg/kg b.w. in PBS).

XVII. Group 17 (DM-rAAGS): DM-r was given combined dose (ratio: 1:1:1:1 w/w) of A. montanus $+A$. gangetica $+G$. latifolium $+S$. melongena $(200 \mathrm{mg} / \mathrm{kg}$ b.w. in PBS).

\section{Fasting plasma glucose concentration}

Blood volumes of $0.2 \mathrm{~mL}$ were drawn from the tail vein of 12 $\mathrm{h}$ post-fasted rats and measured for FPGC at regular intervals of 7 days for 21 days. FPGC was measured using an Accu-Check Sensor Comfort glucometer (Roche, Mexico City) according to the manufacturer's instructions as previously reported. ${ }^{22}$

\section{Lipid profile}

Serum lipid profile (SLP) of $12 \mathrm{~h}$ post-fasted rats was measured on the $21^{\text {th }}$ day of commencement of herbal treatment. SLP parameters, namely, serum triacylglycerol (TAG), total cholesterol (TC) and HDLcholesterol (HDL-C) concentrations were measured using Reflovert Plus instrument (Roche, F. Hoffmann-La Roche, Basel, Switzerland) in accordance to manufacturer's instructions as previously described. ${ }^{20}$ Serum LDL-cholesterol (LDL-C) concentration was measured according to the formula of Friedewald et al. ${ }^{23}$

$$
\mathrm{LDL}-\mathrm{C}=\mathrm{TC}-(\mathrm{HDL}-\mathrm{C})-\left(\frac{\mathrm{TAG}}{5}\right)
$$

Serum VLDL--cholesterol (VLDL-C) concentration was measured 
according to the methods of Burnstein and Sammaille. ${ }^{24}$ Accordingly, serum VLDL-C to TAG concentrations ratio was fixed at 1:5 in $12 \mathrm{~h}$ post-fasting animals.

$$
\text { VLDL }-\mathrm{C}=\frac{\mathrm{TAG}}{5}
$$

Atherogenic Risk Index (ARI) was calculated as previously reported..$^{20}$ Thus:

$$
\mathrm{ARI}=\frac{\mathrm{TC}-(\mathrm{HDL}-\mathrm{C})}{\mathrm{HDL}-\mathrm{C}}
$$

\section{Statistical and data analyses}

The data collected shall be analyzed by one-way analysis of variance procedure while treatment means shall be separated by the least significance difference (LSD) incorporated in the statistical

Table I Fasting plasma glucose concentrations of experimental rat groups analysis system (SAS) package of 9.1 versions, (2006). Values of $p<$ 0.05 were considered statistically significant.

\section{Results}

At the commencement of the experiment (day $=0)$, Group 2 exhibited the highest FPGC compared with those of other experimental rat groups and was 3.02 folds higher than that of Group $1(p<0.05)$. FPGC of Group 3 was not significantly lowered $(p>$ $0.05)$ following herbal treatment for 14 days. However, at the end of the experimental time, FPGC of Group 3 was elevated compared with FPGCs on days 7 and $14(p<0.05)$. Table 1 showed a time-dependent reduction in FPGCs in Group 4, Group 5, Group 7 and Group 8 and Group 9 following 21 days herbal treatment. FPGC of Group 14 was significantly lowered $(p<0.05)$ on the $7^{\text {th }}$ day of herbal treatment, which was followed by time-dependent increase in FPGC on days 14 and $21(p>0.05)$. Finally, FPGC of Group 17 on day 21 was

\begin{tabular}{|c|c|c|c|c|}
\hline Rat Group & FPGC $(\mathrm{mg} / \mathbf{d L})$ & & & \\
\hline & Day 0 & Day 7 & Day 14 & Day 21 \\
\hline Group 1 & $90.0 \pm 6.06^{\mathrm{a}, \mathrm{b}}$ & $102.6 \pm 3.61^{\mathrm{a}}$ & $85.6 \pm 5.95^{\mathrm{a}, \mathrm{b}, \mathrm{c}, \mathrm{d}}$ & $89.6 \pm 1.35^{\mathrm{a}, \mathrm{b}, \mathrm{c}}$ \\
\hline Group 2 & $272.2 \pm 88.35^{\mathrm{a}, \mathrm{b}}$ & $282.5 \pm 77.49^{\mathrm{a}}$ & $257.5 \pm 87.01^{\mathrm{a}, \mathrm{b}, \mathrm{c}, \mathrm{d}}$ & $260.5 \pm 81.78^{\mathrm{a}, \mathrm{b}, \mathrm{c}}$ \\
\hline Group 3 & $242.4 \pm 80.36^{\mathrm{a}}$ & $210.0 \pm 116.5^{\mathrm{c}}$ & $206.2 \pm 115.5^{\mathrm{c}, \mathrm{d}}$ & $231.8 \pm 106.6^{\mathrm{a}, \mathrm{b}}$ \\
\hline Group 4 & $251.3 \pm 98.38^{\mathrm{a}}$ & $237.3 \pm 154.78^{\mathrm{a}, \mathrm{b}}$ & $200.3 \pm 109.73^{c}$ & $151.5 \pm 50.5^{\mathrm{d}}$ \\
\hline Group 5 & $257.8 \pm 122.76^{\mathrm{a}}$ & $211.8 \pm 44.39^{\mathrm{b}}$ & $151.8 \pm 43.31^{\mathrm{c}}$ & $125.5 \pm 43.31^{\mathrm{d}}$ \\
\hline Group 6 & $253.0 \pm 51.98^{\mathrm{a}, \mathrm{b}}$ & $245.4 \pm 78.78^{\mathrm{a}, \mathrm{b}, \mathrm{c}}$ & $254.0 \pm 107.3^{\mathrm{a}}$ & $227.0 \pm 96.08^{\mathrm{c}, \mathrm{d}}$ \\
\hline Group 7 & $256.3 \pm 9.67^{\mathrm{a}}$ & $150.0 \pm 5.20^{\mathrm{b}}$ & $128.5 \pm 8.05^{\mathrm{c}}$ & $112.3 \pm 7.00^{\mathrm{d}}$ \\
\hline Group 8 & $255.9 \pm 8.56^{\mathrm{a}}$ & $154.8 \pm 5.84^{\mathrm{b}}$ & $130.4 \pm 5.88^{\mathrm{c}}$ & $107.2 \pm 5.42^{\mathrm{d}}$ \\
\hline Group 9 & $253.8 \pm 7.66^{\mathrm{a}}$ & $217.9 \pm 8.43^{\mathrm{b}}$ & $193.5 \pm 6.99^{\mathrm{c}}$ & $188.9 \pm 4.89^{\mathrm{c}, \mathrm{d}}$ \\
\hline Group 10 & $259.0 \pm 6.67^{\mathrm{a}}$ & $146.2 \pm 4.89^{\mathrm{b}}$ & $114.4 \pm 4.77^{\mathrm{d}}$ & $129.4 \pm 3.98^{c}$ \\
\hline Group 11 & $245.5 \pm 7.54^{\mathrm{a}}$ & $211.4 \pm 7.93^{\mathrm{b}}$ & $163.0 \pm 7.34^{\mathrm{c}, \mathrm{d}}$ & $174.6 \pm 8.56^{\mathrm{c}}$ \\
\hline Group 12 & $253.8 \pm 8.01^{\mathrm{a}}$ & $194.3 \pm 6.89^{\mathrm{b}}$ & $152,4 \pm 5.23^{\mathrm{c}, \mathrm{d}}$ & $159.1 \pm 5.99^{c}$ \\
\hline Group 13 & $261.2 \pm 7.34^{\mathrm{a}}$ & $179.9 \pm 8.01^{\mathrm{c}, \mathrm{d}}$ & $194.6 \pm 5.88^{b, c}$ & $206.5 \pm 6.77^{\mathrm{b}}$ \\
\hline Group 14 & $258.5 \pm 8.45^{\mathrm{a}}$ & $151.4 \pm 7.44^{\mathrm{b}, \mathrm{c}, \mathrm{d}}$ & $166.4 \pm 5.96^{\mathrm{b}}$ & $161.6 \pm 6.34^{\mathrm{b}, \mathrm{c}}$ \\
\hline Group 15 & $259.8 \pm 7.45^{\mathrm{a}}$ & $165.4 \pm 5.88^{\mathrm{b}}$ & $151.2 \pm 5.33^{\mathrm{b}, \mathrm{c}, \mathrm{d}}$ & $154.4 \pm 4.66^{\mathrm{b}, \mathrm{c}}$ \\
\hline Group 16 & $260.6 \pm 6.55^{\mathrm{a}}$ & $175.3 \pm 4.89^{\mathrm{b}}$ & $154.3 \pm 5.11^{\mathrm{c}, \mathrm{d}}$ & $157.3 \pm 4.43^{\mathrm{c}}$ \\
\hline Group 17 & $258.9 \pm 5.77^{\mathrm{a}}$ & $148.4 \pm 4.23^{\mathrm{b}, \mathrm{c}}$ & $139.5 \pm 4.32^{\mathrm{b}, \mathrm{c}, \mathrm{d}}$ & $160.6 \pm 6.45^{\mathrm{b}}$ \\
\hline
\end{tabular}
significantly elevated $(p<0.05)$ compared to that on day 14 (Table 1$)$.

The mean $(X) \pm$ S.D of $\operatorname{six}(n=6)$ determinations. Means in the rows with the same letter are not significantly different at $p>0.05$ according to LSD.

Serum TAG conentration of Group 3 was significantly different ( $p$ $<0.05$ ) from those of Group 4, Group 6 and Group 9. Blood samples from Group 4, Group 9, Group 11, Group 12, Group 16 and Group 17 gave serum TAG concentrations that varied within a relatively narrow range $(p>0.05)$. Overall, serum TAG concentration of all experimental rat groups was significantly higher $(p<0.05)$ than that of Group 1. Conversely, serum TAG concentration all experimental rat groups was significantly lower $(p<0.05)$ that of Group 2 (Table 2$)$.

Serum TC concentrations of the variuos experimental rat groups were siginficantly $(p<0.05)$ lower than that of Group 2. Likewise, serum TC concentrations of Group 7, Group 8 and Group 11 were significantly lower $(p<0.05)$ than that of Group 1 (Table 2).

Serum HDL-C concentrations of Group 4, Group 5, Group 7 ,
Group 8 and Group 10 showed no significant difference $(p>0.05)$. Likewise, serum HDL-C concentrations were comparable in blood samples from Group 3, Group 11, Group 12, Group 16 and Group $17(p>0.05)$. Among herbal formulation treated rat groups, Group 6, Group 9, Group 13, Group 14 and Group 15 exhibited the relatively low serum HDL-C concentrations (Table 2).

A meticulous look at Table 2 showed that serum LDL-C concentrations of the experimental rat groups exhibited relatively wide variation. Group 2 exhibited the highest serum LDL-C concentration, whereas that of Group 8 gave the lowest serum LDL-C concentration. Serum LDL-C concentrations of herbal formulation treated rat groups were significantly higher $(p<0.05)$ than that of Group 1 . Conversely, serum LDL-C concentrations of herbal formulation treated rat groups were significantly lower $(p<0.05)$ than that of Group 2 . 
Table 2 Serum lipid profile

\begin{tabular}{|c|c|c|c|c|c|}
\hline \multirow[t]{2}{*}{ Rat group } & \multicolumn{5}{|c|}{ Serum Concentrations (mg/dL) } \\
\hline & [TAG] & {$[\mathrm{TC}]$} & {$[$ HDL-C] } & {$[\mathrm{LDL}-\mathrm{C}]$} & [VLDL-C] \\
\hline Group 1 & $112.5 \pm 8.21^{\mathrm{q}}$ & $80.8 \pm 4.17^{\mathrm{f,g,h}}$ & $48.9 \pm 2.52^{\mathrm{a}}$ & $9.40 \pm 0.59^{\circ}$ & $22.5 \pm 8.21^{q}$ \\
\hline Group 2 & $189.6 \pm 11.63^{\mathrm{a}}$ & $105.4 \pm 6.01^{\mathrm{a}}$ & $20.8 \pm 1.35^{q}$ & $46.68 \pm 4.01^{\mathrm{a}}$ & $37.9 \pm 11.63^{\mathrm{a}}$ \\
\hline Group 3 & $167.5 \pm 10.95^{\mathrm{b}}$ & $85.3 \pm 5.01^{\mathrm{c}, \mathrm{d}, \mathrm{e}, \mathrm{f}}$ & $28.9 \pm 1.92^{g, h}$ & $22.90 \pm 2.59^{\mathrm{h}}$ & $33.5 \pm 10.95^{\mathrm{b}}$ \\
\hline Group 4 & $153.9 \pm 10.88^{\mathrm{b}, \mathrm{c}, \mathrm{d}, \mathrm{e}}$ & $80.7 \pm 4.16^{\mathrm{fg}, \mathrm{hh}, \mathrm{h}, \mathrm{i}}$ & $38.2 \pm 2.14^{\mathrm{b} . \mathrm{c}}$ & $11.72 \pm 0.65^{\mathrm{m}}$ & $30.8 \pm 10.88^{\mathrm{b}, \mathrm{c}, \mathrm{d}, \mathrm{e}}$ \\
\hline Group 5 & $133.5 \pm 9.56^{\mathrm{m}, \mathrm{n}}$ & $78.9 \pm 4.01^{\mathrm{f}, \mathrm{g}, \mathrm{h}, \mathrm{I}, \mathrm{j}, \mathrm{k}}$ & $38.5 \pm 2.16^{\mathrm{b}}$ & $13.70 \pm 0.83^{\mathrm{k}, 1}$ & $26.7 \pm 9.56^{\mathrm{m}, \mathrm{n}}$ \\
\hline Group 6 & $166.9 \pm 10.88^{\mathrm{b}, \mathrm{c}}$ & $94.8 \pm 5.59^{b}$ & $23.7 \pm 1.88^{\mathrm{l}, \mathrm{m}, \mathrm{n}, \mathrm{o}, \mathrm{p}}$ & $37.72 \pm 3.86^{\mathrm{b}}$ & $33.4 \pm 10.88^{\mathrm{b}, \mathrm{c}}$ \\
\hline Group 7 & $129.5 \pm 8.96^{\mathrm{n}, \mathrm{o}}$ & $66.9 \pm 3.80^{\mathrm{op} p}$ & $36.9 \pm 2.01^{\mathrm{b}, \mathrm{c}, \mathrm{d}}$ & $4.10 \pm 0.11^{\mathrm{p}}$ & $25.9 \pm 8.96^{\mathrm{n}, \mathrm{o}}$ \\
\hline Group 8 & $126.4 \pm 8.84^{\mathrm{n}, 0, \mathrm{p}}$ & $61.7 \pm 3.75^{\mathrm{p}, \mathrm{q}}$ & $35.3 \pm 1.94^{\mathrm{b}, \mathrm{c}, \mathrm{d}, \mathrm{e}, \mathrm{f}}$ & $1.12 \pm 0.09^{q}$ & $25.3 \pm 8.84^{\mathrm{n}, 0, \mathrm{p}}$ \\
\hline Group 9 & $153.6 \pm 10.72^{\mathrm{b}, \mathrm{c}, \mathrm{de}, \mathrm{f}}$ & $89.5 \pm 5.10^{\mathrm{b}, \mathrm{c}, \mathrm{d}}$ & $24.9 \pm 1.89^{1}$ & $33.88 \pm 3.41^{\mathrm{c}}$ & $30.7 \pm 10.72^{\mathrm{b}, \mathrm{c}, \mathrm{d}, \mathrm{e}, \mathrm{f}}$ \\
\hline Group 10 & $141.1 \pm 10 .^{11 \mathrm{~d}, \mathrm{e}, \mathrm{f}, \mathrm{g}, \mathrm{h}, \mathrm{I}, \mathrm{j}, \mathrm{k}, \mathrm{l}, \mathrm{m}}$ & $78.5 \pm 3.98^{\mathrm{f}, \mathrm{g}, \mathrm{h}, \mathrm{I}, \mathrm{j}, \mathrm{k}, \mathrm{l}}$ & $35.6 \pm 2.10^{\mathrm{b}, \mathrm{c}, \mathrm{d}, \mathrm{e}}$ & $14.68 \pm 1.01^{\mathrm{k}}$ & $28.2 \pm 10.11^{\mathrm{d}, \mathrm{e}, \mathrm{f}, \mathrm{g}, \mathrm{h}, \mathrm{I}, \mathrm{j}, \mathrm{k}, \mathrm{l}, \mathrm{l}, \mathrm{m}}$ \\
\hline Group 11 & $148.6 \pm 10 .^{16 \mathrm{~d}, \mathrm{e}, \mathrm{f}, \mathrm{g}, \mathrm{h}, \mathrm{I}, \mathrm{j}}$ & $69.4 \pm 3.89^{\circ}$ & $28.5 \pm 1.94^{\mathrm{g}, \mathrm{h}, \mathrm{I}, \mathrm{j}}$ & $11.18 \pm 0.61^{\mathrm{m}, \mathrm{n}}$ & $29.7 \pm 10.16^{\mathrm{de}, \mathrm{f}, \mathrm{g}, \mathrm{h}, \mathrm{I}, \mathrm{j}, \mathrm{j}}$ \\
\hline Group 12 & $149.1 \pm 10.22^{\text {d,eff.g.h }}$ & $89.1 \pm 5.11^{\mathrm{b}, \mathrm{c}, \mathrm{d}, \mathrm{e}, \mathrm{f}}$ & $30.1 \pm 1.79^{g}$ & $29.18 \pm 2.69^{\mathrm{e}}$ & $29.8 \pm 10.22^{\text {d,e,f.g.h }}$ \\
\hline Group 13 & $159.5 \pm 10.89^{\mathrm{b}, \mathrm{c}, \mathrm{d}}$ & $89.9 \pm 5.16^{\mathrm{b}, \mathrm{c}}$ & $24.8 \pm 1.88^{1, \mathrm{~m}, \mathrm{n}}$ & $33.20 \pm 3.23^{\mathrm{c}, \mathrm{d}}$ & $31.9 \pm 10.89^{\mathrm{b}, \mathrm{c}, \mathrm{d}}$ \\
\hline Group 14 & $143.9 \pm 10.22^{\mathrm{d}, \mathrm{e}, \mathrm{f}, \mathrm{g}, \mathrm{h}, \mathrm{I}, \mathrm{j}, \mathrm{k}, \mathrm{l}}$ & $79.2 \pm 4.04^{\text {f,g.h.i.j }}$ & $23.8 \pm 1.69^{1, \mathrm{~m}, \mathrm{n}, \mathrm{o}}$ & $26.62 \pm 2.51^{\mathrm{e}, \mathrm{f}, \mathrm{g}}$ & $28.8 \pm 10.22^{\mathrm{d}, \mathrm{e}, \mathrm{f}, \mathrm{g}, \mathrm{h}, \mathrm{I}, \mathrm{j}, \mathrm{j}, \mathrm{l}, \mathrm{l}}$ \\
\hline Group 15 & $144.4 \pm 10.25^{\mathrm{d}, \mathrm{e}, \mathrm{f}, \mathrm{g}, \mathrm{h}, \mathrm{I}, \mathrm{j}, \mathrm{j}, \mathrm{k}}$ & $83.9 \pm 4.98^{\mathrm{c}, \mathrm{d}, \mathrm{e}, \mathrm{f}, \mathrm{g}}$ & $26.8 \pm 1.89^{1, \mathrm{~m}}$ & $28.22 \pm 2.43^{\mathrm{e}, \mathrm{f}}$ & $28.9 \pm 10.25^{\mathrm{d}, \mathrm{e}, \mathrm{f}, \mathrm{g}, \mathrm{h}, \mathrm{L}, \mathrm{j}, \mathrm{k}}$ \\
\hline Group 16 & $149.8 \pm 10.21^{\mathrm{d}, \mathrm{e}, \mathrm{f}, \mathrm{g}}$ & $76.9 \pm 3.99^{\mathrm{g}, \mathrm{h}, \mathrm{l}, \mathrm{j}, \mathrm{k}, \mathrm{l}, \mathrm{m}, \mathrm{n}}$ & $27.9 \pm 1.87^{\mathrm{g}, \mathrm{h}, \mathrm{I}, \mathrm{j}, \mathrm{k}}$ & $19.04 \pm 1.24^{\mathrm{i}, \mathrm{j}}$ & $29.9 \pm 10.21^{\mathrm{d}, \mathrm{e}, \mathrm{f}, \mathrm{g}}$ \\
\hline Group 17 & $148.7 \pm 10.21^{\mathrm{de}, \mathrm{f}, \mathrm{g}, \mathrm{h}, \mathrm{i}}$ & $77.9 \pm 3.91^{\mathrm{g}, \mathrm{h}, \mathrm{I}, \mathrm{j}, \mathrm{k}, \mathrm{l}, \mathrm{m}}$ & $28.7 \pm 1.84^{\mathrm{g}, \mathrm{h}, \mathrm{i}}$ & $19.46 \pm 1.35^{\mathrm{i}}$ & $29.7 \pm 10.21^{\mathrm{d}, \mathrm{e}, \mathrm{f}, \mathrm{g}, \mathrm{h}, \mathrm{i}}$ \\
\hline
\end{tabular}

The mean $(X) \pm$ S.D of $\operatorname{six}(n=6)$ determinations. Means in the column with the same letter are not significantly different at $p>0.05$ according to LSD.

Serum VLDL-C concentrations of the experimental rat groups followed the same pattern with that of serum TAG concentrations (Table 2). Expectedly, serum VLDL-C concentrations were approximately 5 folds higher serum TAG concentrations of corresponding rat groups.

Group 2 exhibited the highest ARI compared with other experimental rat groups $(p<0.05)$ (Figure 1). Group 1 gave the lowest ARI and was not significantly different $(p>0.05)$ from that of Group 8 . ARI of herbal formulation treated rat groups were significantly ( $p<$ $0.05)$ lower than that of Group 2. However, ARI of herbal formulation treated rat groups were significantly higher $(p<0.05)$ than that of Group 1; except those of Group 7 and Group $8(p>0.05)$. An overview of Figure 1 showed that ARI of Group 3, Group 12 and Group 15 exhibited no significant difference $(p>0.05)$

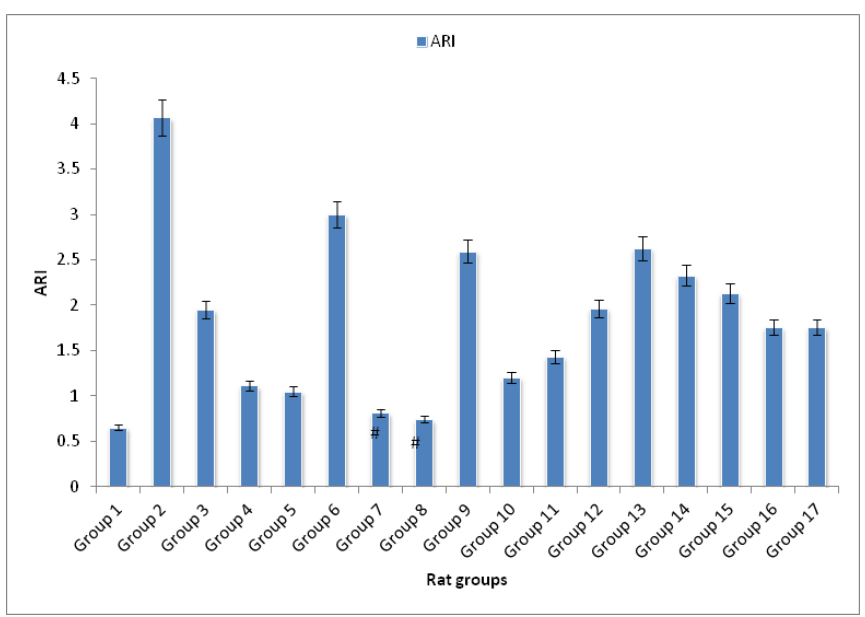

Figure I Atherogenic Risk Index (ARI) of experimental rat groups \#:ARI was not significantly different $(p>0.05)$ from normal rat group (Group I) according to LSD

\section{Discussion}

Bioactive principles from medicinal plants have been established to exert glycemic control and reverse dyslipidemia in diabetic animal models by diverse mechanisms, notable among which are modulation of enzyme activities or gene expressions connected with antioxidants, glucose and lipid homeostasis, ${ }^{25}$ stimulation of insulin secretion/ mimicry, ${ }^{17,26,27}$ improvement of hepatic glutathione concentration, ${ }^{26}$ and inhibition of intestinal absorption of glucose. ${ }^{27}$ Several studies have also shown that bioactive principles exert glycemic control by inhibition of intestinal $\alpha$-glycosidase, pancreatic lipase and cholesterol esterase activities, ${ }^{28}$ facilitating muscle uptake of glucose,${ }^{29}$ regeneration/proliferation of $\beta$-cells, ${ }^{17}$ promotion of insulin and adrenaline secretions as well as exhibition of anti-oxidative activity. ${ }^{26,27}$ Reviews on bioactive principles from anti-diabetic plants and their mechanisms of effecting glycemic control have exhaustively been described elsewhere. ${ }^{17,18}$ Bioactive principles that have been implicated in glycemic control include glycosides, alkaloids, terpenoids, flavonoids, $\beta$-sitosterol, pectin, saponins etc. ${ }^{27}$ Previous empirical analyses elsewhere, ${ }^{1,4,8-10}$ of phytochemical and nutrient compositions the four herbal formulations, namely, A. montanus, $A$. gangetica, G. latifolium and S. melongena used in the present study showed that they contain substantial quantities of bioactive principles noted to reverse hyperglycemia and dyslipidemia.

The DHFs exerted relatively greater glycemic control, exemplified by reductions in FBGCs of DM-rAGAM and DM-rAGGL, than those of experimental rat groups administered SHFs. However, glycemic control in DM-rGOLA, which received SHF, was comparable to those of DM-rAGAM and DM-rAGGL. Furthermore, THFs and QHF appeared to exert comparable glycemic control in DM-r. Previous reports have shown that the capacities of single and combinatorial herbal formulations to exert glycemic control in DM-r were outcomes of cumulative molecular interactions amongst the constituent 
phytochemicals of the various herbal formulations, whose gross effect to adjust FBGC could either be synergistic or antagonistic. ${ }^{30}$ According to Ojiako et al. ${ }^{20}$ combinatorial herbal formulations profoundly altered the relative concentrations of bioactive principles and nature of their cumulative molecular interactions in solution, which invariably altered the therapeutic potentials of the administered herbal formulations. However, the present study showed that SHFs, DHFs, THFs and QHF did not offer full therapeutic benefits within the experimental 21 days of treatment.

Previous studies showed that hyperglycemia provoked by DM is associated with dyslipidemia in both animal models and humans..$^{26,27,31}$ Furthermore, reports showed that herbal extracts ameliorated dyslipidemia concomitantly with hyperglycemia in animal models. ${ }^{26}$ In concord with previous reports, ${ }^{27}$ the present study showed that single and combinatorial herbal formulations reversed dyslipidemia alongside hyperglycemia in DM-r. Specifically, Visavadiya and Narasimhacharya, ${ }^{31}$ noted that the capacities of combinatorial root extracts of Glycyrrhiza glabra, Withania somnifera, Asparagus racemosus, Chlorophytum borivilianum and seeds of Sesamum indicum to reduce plasma and hepatic cholesterol concentrations were connected with increased fecal excretion of cholesterol, neutral sterol, and bile acid as well as increased hepatic 3-hydroxy-3-methyl-glutaryl coenzyme A (HMG-CoA) reductase activity and bile acid content in hypercholesterolemia rats. They further noted the presence of fibers, saponins, phytosterols, polyphenols, flavonoids and ascorbic acid in the combinatorial root extracts, amongst which phytosterols, fibers as well as saponins were implicated in facilitating the elimination of cholesterol in hypercholesterolemia rats administered the herbal combinations.

Elevated serum TAG concentration in untreated DM-r was an indication of absence of critical intracellular events leading to the activation of lipoprotein lipase responsible for the hydrolysis of TAG prior uptake by peripheral tissues as previously reported. ${ }^{32}$ Thus, alloxan-targeted destruction of $\beta$-cells results in depletion of circulating plasma insulin levels, which in turn caused failure in activation of lipoprotein lipase. Absence of insulin mediated activation of lipoprotein lipase engendered dyslipidemia-hypercholesterolemia, hyperglyceridemia and associated metabolic abnormalities. ${ }^{33}$ Furthermore, dyslipidemia in DM state is associated with increased fatty acid mobilization from adipose tissue to peripheral tissues. ${ }^{34}$ Increased circulating plasma free fatty acids, following the activation of lipoprotein lipase, engenders exacerbated $\beta$-oxidation, which in turn causes overwhelming tissue levels of acetyl-CoA thereby fostering enhanced rate of biosynthesis of cholesterol. ${ }^{27}$ Overall, the outcome of the present study was indicative of distortions in lipid metabolism, promoting high circulating level of plasma free fatty acids, which for the most part is responsible for elevated serum TC concentration as typified in the DIAB group. Additionally, absence of circulating insulin in plasma or insulin insufficiency is associated with poorly regulated HMG-CoA activity, ${ }^{34}$ which results in exacerbated biosynthesis of cholesterol with consequential presentation of hypercholesterolemia as typified in the DIAB group.

Previous reports, according to Venkatesan et al. ${ }^{35}$ showed that lowered serum TAG concentration following herbal treatment was probably connected with the capability of the fiber and saponins contents of the herb to retard absorption of lipids from the intestinal lumen and inhibit pancreatic lipase, respectively. Low serum TAG concentration invariably indicated corresponding reduction in plasma VLDL-C as previously described. ${ }^{36}$ Accordingly, substantial reduction in serum TAG concentrations in DM-rAGAM and DM-rAGGL, as reported in the present study, was probably connected with the fiber and saponins contents of the corresponding herbal formulations administered to the rats.

Empirical data have shown that elevated serum HDL-C concentration provides protective role against development and progression of cardiovascular disease. ${ }^{37}$ Therefore, raised serum HDL-C concentration is anti-atherogenic, inhibit LDL oxidation and protect endothelial cells from the cytotoxic effect of oxidized LDL. ${ }^{38}$ Studies have shown that ascorbic acid and flavonoids promote elevated serum HDL-C concentration in hamsters, ${ }^{39}$ whereas dietary saponins and fibers have not been established to increase serum HDL-C concentration. ${ }^{35}$ The present study showed that DM-r that received SHFs, namely, DM-rASGA, DM-rGOLA as well as those that received DHFs, namely, DM-rAGAM DM-rAGGL DMrAMGL exhibited elevated serum HDL-C concentration compared to untreated DM-r (DIAB group). On the contrary, DM-r that received SHFs, specifically, DM-rSOME exhibited relatively low serum HDL-C concentration with corresponding high ARI. These findings were indications that the molecular interactions and peculiarities of bioactive principles present in the various extracts dictated their capacities to adjust serum HDL-C concentrations in DM-r as well as their corresponding ARI. Previous findings corroborated the outcome of the present study, in that the administration of polyherbal formulation reversed hyperlipidemia and peroxidative damage to tissues of alloxan-induced hyperglycemic rats..$^{27,31}$

Conversely, the present study showed that raised serum LDL-C concentration may contribute to high ARI as exemplified in DIAB, DMrSOME, DM-rAGSM and DM-rAGGS. Previous reports indicated that the absence of circulating insulin in plasma or low circulating levels of insulin in plasma caused repression of receptor-mediated removal of LDL-C in plasma, engendering hypercholesterolemia. ${ }^{27}$

\section{Conclusion}

The present study showed that selected DHFs, notably, $A$. gangetica $+A$. montanus and $A$. gangetica $+G$. latifolium offered greater glycemic control than other herbal formulations and reversed dyslipidemia in experimental rat groups as exemplified in DMrAGAM and DM-rAGGL. Overall, the herbal formulations exhibited differential capacities to ameliorate hyperglycemia and dyslipidemia in alloxan-induced diabetic but they did not offer full therapeutic benefit within the experimental time of 21 days. The present study suggests that the differential capacities of SHFs, DHFs, THFs and QHF to reverse hyperglycemia and dyslipidemia in alloxan-induced DM-r were as a result of synergistic and/or antagonistic interactions amongst constituent phytochemicals in the herbal formulations. Accordingly, phytochemical interactions obviously dictated the therapeutic scores and potentials of the various herbal combinations.

As a result of the favourable biochemical outcomes in DM-r following the administration of the specified herbal formulations, further studies using bioassay-guided approach is required to identify the bioactive principles from the herbal formulations in order to isolate and characterize the therapeutic biomolecules as well as elucidate their mechanisms of therapeutic actions.

\section{Acknowledgments}

The authors are grateful for the technical assistance offered by Mr. O.A.K. Emenyonu, Chief Academic Technologist, Department of Biochemistry, Imo State University, Owerri, and Imo State, Nigeria. 


\section{Conflicts of interest}

The authors declare that there is no conflict of interest regarding the publication of this article.

\section{References}

1. Okoli CO, Akah PA, Onuoha NJ, et al. Acanthus montanus: An experimental evaluation of the antimicrobial, anti-inflammatory and immunological properties of a traditional remedy for furuncles. $B M C$ Compl Altern Med. 2008;8:27.

2. Kensa VM. Studies on phytochemical profile and antimicrobial activity on Asystasia gangetica (L.) T. Anderson. Plant Sci Feed. 2011;1:112-117.

3. Ugochukwu NH, Babady NE, Cobourne M, et al. The effect of Gongronema latifolium extracts on serum lipid profile and oxidative stress in hepatocytes of diabetic rats. $J$ Biosci. 2003;28:1-5.

4. Eleyinmi AF. Chemical composition and antibacterial activity of Gongronema latifolium. J Zhejiang Univ Sci. 2007;8:352-358.

5. Akuodor GC, Idris UM, Anyalewechi N, et al. In vivo antimalarial activity of ethanolic leaf extract of Verbena hastata against Plasmodium berghei in mice. J Herb Med Toxicol. 2010;4:17-23.

6. Egunyomi A, Moody JO, Eletu OM. Antisickling activities of two ethnomedicinal plant recipes used for the management of sickle cell anaemia in Ibadan, Nigeria. Afr J Biotechnol. 2009;8:20-25.

7. Das M, Barua N. Pharmacological activities of Solanum melongena Linn. (Brinjal plant). Int J Green Pharm. 2013;7:274-277.

8. Rotimi SO, Omotosho OE, Rotimi OA. Persistence of acidosis in alloxan-induced diabetic rats treated with the juice of Asystasia gangetica leaves. Pharmacogn Mag. 2011;7:25-30.

9. Agoreyo BO, Obansa ES, Obanor EO. Comparative nutritional and phytochemical analyses of two varieties of Solanum melongena. Sci World J. 2012;7:5-8.

10. Gopal TK, Megha G, Chamundeeswari D, et al. Phytochemical and pharmacological studies on whole plant of Asystasia gangetica. Indian $J$ Res Pharm Biotechnol. 2013;1:365-370.

11. Wild S, Roglic G, Green A. Global prevalence of diabetes: estimate for the year 2000 and projection for 2030. Diabetes Care. 2004;27:1047-1053.

12. Rheeder P. Type II diabetes: the emerging epidemic. Nig Fam Pract. 2006; $48: 20$

13. Bahadoran Z, Mirmiran P, Azizi F. Dietary polyphenols as potential nutraceuticals in management of diabetes: A review. J Diabetes Metab Disord. 2013;12:9.

14. Velho G, Froguel P. Maturity-onset diabetes of the young (MODY), MODY genes and non-insulin dependent diabetes mellitus. Diabetes. 2002;23:34-43.

15. Steiner G. Atherosclerosis, the major complication of diabetes. Adv Exp Med Biol. 1985;189:277-297.

16. Taskinen MR, Beltz WF, Harper I, et al. Effects of NIDDM on very-lowdensity lipoprotein triglyceride and apolipoprotein B metabolism. Studies before and after sulfonylurea therapy. Diabetes. 1986;35:1268-1277.

17. Patel DK, Prasad SK, Kumar R, et al. An overview on antidiabetic medicinal plants having insulin mimetic property. Asian Pac J Trop Biomed. 2012;2(4):320-330.

18. Jung M, Park M, Lee HC, et al. Anti-diabetic agents from medicinal plants. Curr Med Chem. 2006;13:1203-1218.

19. Wang F, Zhao S, Li F, et al. Investigation of antioxidant interactions between Radix Astragali and Cimicifuga foetida and identification of synergistic antioxidant compounds. Plos One. 2014;9:87221.
20. Ojiako AO, Chikezie PC, Ogbuji CA. Blood glucose level and lipid profile of alloxan-induced hyperglycemic rats treated with single and combinatorial herbal formulations. $J$ Tradit Compl Med. 2016;6:184-192

21. Madhavan V, Joshi R, Murali A, et al. Antidiabetic activity of Curculigo orchioides root tuber. Pharmaceut Biol. 2007;45:18-21.

22. Juarez-Rojop IE, Tovilla-Zarate CA, Aguilar-Dominguez DE, et al Phytochemical screening and hypoglycemic activity of Carica papaya leaf in streptozotocin-induced diabetic rats. Rev Braz Farmacogn. 2014:24:341-347.

23. Friedewald W, Levy R, Fredrickson D. Estimation of concentration of low-density lipoprotein in plasma, without use of the preparative ultracentrifuge. Clin Chem. 1972;18:499-502.

24. Burnstein MA, Sammaille J. A rapid determination of cholesterol bound to A and B-lipoprotein. Clin Chem Acta. 1960;5:601-609.

25. Jung UJ, Park YB, Kim SR, et al. Supplementation of persimmon leaf ameliorates hyperglycemia, and hepatic fat accumulation in type 2 diabetic mice. PLoS One. 2012;7:30.

26. El-Missiry MA, El Gindy AM. Amelioration of alloxan induced diabetes mellitus and oxidative stress in rats by oil of Eruca sativa seeds. Ann Nutr Metab. 2000;44:97-100.

27. Saravanan G, Pari L. Hypoglycaemic and antihyperglycaemic effect of Syzygium cumini bark in streptozotocin-induced diabetic rats. $J$ Pharmacol Toxicol. 2008;3:1-10.

28. Toma A, Makonnen E, Mekonnen Y, et al. Intestinal $\alpha$-glucosidase and some pancreatic enzymes inhibitory effect of hydroalcholic extract of Moringa stenopetala leaves. BMC Compl Altern Med. 2014;14:180.

29. Jadhav R, Puchchakayala G. Hypoglycemic and antidiabetic activity of flavonoids: boswellic acid, ellagic acid, quercetin, rutin on streptozotocin-nicotinamide induced type 2 diabetic rats. Int $J$ Pharm Pharmaceut Sci. 2012;4:251

30. Milugo TK, Omosa LK, Ochanda JO, et al. Antagonistic effect of alkaloids and saponins on bioactivity in the quinine tree (Rauvolfia (affrasond): further evidence to support biotechnology in traditional medicinal plants. BMC Compl Altern Med. 2013;13:285.

31. Visavadiya NP, Narasimhacharya AV. Ameliorative effects of herbal combinations in hyperlipidemia. Oxid Med Cell Longev. 2011:8.

32. Gutierrez RMP, Gomez YGY, Guzman MD. Attenuation of nonenzymatic glycation, hyperglycemia, and hyperlipidemia in streptozotocin-induced diabetic rats by chloroform leaf extract of Azadirachta indica. Pharmacogn Mag. 2011; 7:254-259.

33. Maghrani M, Zeggwagh NA, Lemhadri A, et al. Study of the hypoglycaemic activity of Fraxinus excelsior and Silybum marianum in an animal model of type 1 diabetes mellitus. $J$ Ethnopharmacol 2004:91:309-316.

34. Pierre W, Gildas AJH, Ulrich MC, et al. Hypoglycemic and hypolipidemic effects of Bersama engleriana leaves in nicotinamide/ streptozotocin-induced type 2 diabetic rats. BMC Compl Altern Med. 2012;12:264.

35. Venkatesan N, Devaraj SN, Devaraj H. Increased binding of LDL and VLDL to apo B, E receptors of hepatic plasma membrane of rats treated with Fibernat. Eur J Nutr. 2003;42:262-271.

36. Howell TJ, MacDougall DE, Jones PJH. Phytosterols partially explain differences in cholesterol metabolism caused by corn or olive oil feeding. J Lipid Res. 1998;39:892-900. 
37. Mensink RP, Zock PL, Kester AD, et al. Effects of dietary fatty acids and carbohydrates on the ratio of serum total to HDL cholesterol and on serum lipids and apolipoproteins: a meta-analysis of 60 controlled trials. Am J Clin Nutr. 2003;77:1146-1155.

38. Assmann G, Nofer JR. Atheroprotective effects of high-density lipoproteins. Ann Rev Med. 2003;54:321-341.
39. Vinson JA, Hu SJ, Jung S, et al. A citrus extract plus ascorbic acid decreases lipids, lipid peroxides, lipoprotein oxidative susceptibility, and atherosclerosis in hypercholesterolemic hamsters. J Agric Food Chem. 1998;46:1453-1459. 